\title{
METHODS TO BREAK SEED DORMANCY OF Rhynchosia capitata, A SUMMER ANNUAL WEED
}

\author{
Hafiz Haider Ali ${ }^{1 *}$, Asif Tanveer ${ }^{1}$, Muhammad Ather Nadeem ${ }^{1}$, and Hafiz Naeem Asghar ${ }^{2}$
}

\begin{abstract}
Dormancy of weed seeds is a significant feature contributing to their survival rate since it helps the weeds to avoid herbicides and other weeding practices along with unfavorable environmental conditions. We investigated the effects of different dormancy breaking treatments on the germination of Rhynchosia capitata, a common summer annual weed, which is emerging as a weed threat in Pakistan. Seeds were soaked in thiourea, $\mathrm{KNO}_{3}, \mathrm{HCl}, \mathrm{HNO}_{3}$, and $\mathrm{H}_{2} \mathrm{SO}_{4}$, and they were also mechanically scarified (sandpaper). Results indicated that $R$. capitata seeds show signs of physical dormancy that is mainly due to the impermeability of their coat. Mechanical scarification and acid scarification (soaking of seeds in $\mathrm{H}_{2} \mathrm{SO}_{4}$ for 60 and $80 \mathrm{~min}$ and in $\mathrm{HCl}$ for 12 and $15 \mathrm{~h}$ ) were very efficient in breaking dormancy and promoting germination. Seed soaking in $\mathrm{HNO}_{3}$ for 1 to $5 \mathrm{~d}$ showed little effect whereas various concentrations of thiourea and $\mathrm{KNO}_{3}$ were ineffective in breaking $R$. capitata seed dormancy.
\end{abstract}

Key words: $\mathrm{HCl}, \mathrm{HNO}_{3}, \mathrm{H}_{2} \mathrm{SO}_{4}$, dormancy, germination.

$\mathrm{T}$ he genus Rhynchosia is widely distributed among several species occurring in the mountainous regions of the tropics. Basic similarities of various species of Rhynchosia are pinnate leaves, compressed pods, and nonaccrescent calyx (Adinarayana et al., 1985). Rhynchosia capitata, a member of the Fabaceae family, is indigenous to Pakistan (Jahan et al., 1994), India (Dogra et al., 2009), and Sri Lanka (ILDIS, 2010). It has invaded the cultivated areas of Southern Punjab in Pakistan and is making things difficult for farmers

In the field, the plant appears through the seed just after irrigation; it is an annual twinning prostrate plant with many branches spreading all around the root stock and rooting at every node. An approximately 1-mo-old plant starts flowering with oval-shaped pods with two seeds in each pod. Seeds are spherical and usually brown in color. Seeds mature within 3 mo when the plants also starts to dry (Sharma et al., 1978). The growing season is from May to October with minimum and maximum average temperatures of $29 / 21 \pm 3{ }^{\circ} \mathrm{C}$ and $39 / 29 \pm 3{ }^{\circ} \mathrm{C}$, respectively, and average rainfall of $650 \mathrm{~mm}$.

Seed dormancy is an innate seed property that defines the environmental conditions in which the seed is able to germinate (Finch-Savage and Leubner-Metzger, 2006). An understanding of dormancy mechanisms is of ecological

${ }^{1}$ University of Agriculture, Department of Agronomy, Faisalabad, Pakistan. ${ }^{*}$ Corresponding author (haider3993@gmail.com).

${ }^{2}$ University of Agriculture, Institute of Soil and Environmental Sciences, Faisalabad, Pakistan.

Received: 15 January 2011.

Accepted: 30 June 2011. and economic importance. Weed seed dormancy and germination are regulated by a complex interaction of environmental, edaphic, physiological, and genetic factors (Radosevich et al., 1996). The relationship between seed dormancy and the success of a plant as an agricultural weed is significant. Weed seeds vary extensively with respect to degree, duration, and dormancy source. The existence of large weed seed populations with varying degrees and states of dormancy is the basis for the annual weed problem.

Dormancy is a common attribute of many weed seed populations and this usually hampers the task of predicting the timing and extent of weed emergence (Roberto et al., 2000). Brasil (2009) examined that among 260 leguminoseae seeds, about $85 \%$ had tegument impermeable to water. Tegument impermeability is associated with the presence of impermeable layers of palisade cells (Baskin and Baskin, 1998). This kind of dormancy could be overcome by weakening the tegument by allowing water to pass and initiate germination (Cavalheiro et al., 2007). This process can also occur through the action of acids during seed digestion by dispersing animals (Goddard et al., 2009).

Many species of the Fabaceae family such as Lupinus spp. seeds exhibit dormancy that is primarily due to water impermeability of the seed's coat. Scarification of Texas bluebonnet (Lupinus texensis Hook) seeds with sulfuric acid for 30 to $60 \mathrm{~min}$ improved seedling emergence (Davis et al., 1991). Acid scarification of big bend bluebonnet (Lupinus havardii S. Wats) seeds for $120 \mathrm{~min}$ and perennial lupine (Lupinus perennis Wats.) 
seeds for 45 min resulted in 100\% germination (Mackay et al., 1996). The concentrated sulfuric acid treatment has been widely used to improve seed germination of several hard seed coat species (Tigabu and Oden, 2001).

Weed control is an integral part of efficient crop production that is assisted by new methods of dormancy release (Gu et al., 2004). Dormancy levels differ between individual seeds within a population. Changing weed seed dormancy levels is probably the most important process that determines weed emergence patterns under field situations. Predicting weed seed dormancy and consequently, timing and extent of weed emergence, is important in order to improve weed control strategies (Radosevich et al., 1996).

Dormancy can distribute seed germination in the soil over the years, so weeds continue to emerge in the field even after years of thorough weed management practices. Weeds are difficult to eliminate in a field because seed banks provide an enormous seed collection with different dormancy levels. Thus, seed dormancy is a major cause of continuing weed problems, but no information is available about breaking seed dormancy of $R$. capitata worldwide. The present study was therefore conducted with the hypothesis of whether $R$. capitata seeds could be released from dormancy with different seed treatment methods. The objective of this research was to determine the effect of different methods and identify the best method to break seed dormancy and promote germination of $R$. capitata seeds.

\section{MATERIALS AND METHODS}

\section{Seed collection}

Mature $R$. capitata pods were collected from the Vigna radiata (L.) R. Wilczek field in October 2009. Immediately after collection, seeds were isolated from the pods, separated from the undesired materials and unripe seeds, and stored in sealed paper bags after drying for 1 wk in the shade under normal room temperature (25 to 30 ${ }^{\circ} \mathrm{C}$ ); only mature and uniformly-sized seeds were used in various seed germination experiments.

Experiment 1: Effect of seed treatment with $\mathrm{KNO}_{3}$ and thiourea on dormancy release and germination of R. capitata

Seeds were soaked in different concentrations of potassium nitrate $\left(\mathrm{KNO}_{3}\right)(0,10000,20000,30000$, 40000,50000 , and $60000 \mathrm{mg} \mathrm{L}^{-1}$ and thiourea $\left[\left(\mathrm{NH}_{2}\right)_{2} \mathrm{C}\right.$ S] $\left(0,2500,5000,7500\right.$, and $\left.10000 \mathrm{mg} \mathrm{L}^{-1}\right)$ for $24 \mathrm{~h}$ at $30{ }^{\circ} \mathrm{C}$. The concentration ranges were selected after preliminary trials in which seeds were immersed in $\mathrm{KNO}_{3}$ at concentrations of 0,500,1 000, 2500,5000 , and $7500 \mathrm{mg} \mathrm{L}^{-1}$, and thiourea at concentrations of 100 , 200, 300, 400, 500, 600, and $1000 \mathrm{mg} \mathrm{L}^{-1}$, which had no effect on dormancy.
Experiment 2: Effect of seed scarification with $\mathrm{HCl}$ and sandpaper on dormancy release and germination of $R$. capitata

Seeds were immersed separately in $\mathrm{HCl}(36 \%)$ for 3, 6, $9,12,15$, and $18 \mathrm{~h}$ at $30^{\circ} \mathrm{C}$ in addition to being rubbed against the rough surface of the sandpaper (the seed coat was sanded with a \# 80 wood sandpaper at an area opposite from the embryo until the cotyledon was exposed). Immediately after the prescribed soaking period, seeds were removed and rinsed several times in clean distilled water. Untreated seeds were used as a control.

\section{Experiment 3: Effect of seed scarification with $\mathrm{HNO}_{3}$} on dormancy release and germination of $\boldsymbol{R}$. capitata

Seeds were treated separately with $\mathrm{HNO}_{3}(65 \%)$ for 1,2 , 3,4 , and $5 \mathrm{~d}$ at $30^{\circ} \mathrm{C}$. Seeds were then rinsed several times in clean distilled water after the treatment with acids. Untreated seeds were used as a control.

Experiment 4: Effect of seed scarification with $\mathrm{H}_{2} \mathrm{SO}_{4}$ on dormancy release and germination of $R$. capitata

In this experiment, seeds were soaked in sulfuric acid (98\%) for $20,40,60,80,100$, and $120 \mathrm{~min}$ at $30^{\circ} \mathrm{C}$. These treatments were selected after conducting preliminary trials of soaking seeds in sulfuric acid for $2,4,6,8$, and $10 \mathrm{~min}$, which had no effect on breaking dormancy. Thereafter, scarified seeds were rinsed several times in clean distilled water. Untreated seeds were used as a control.

\section{Germination test}

After rinsing, seeds were allowed to dry on blotter paper at the laboratory temperature $\left(30^{\circ} \mathrm{C}\right)$ before being placed in Petri dishes in the abovementioned experiments. Seeds were surface sterilized by soaking in a $5 \%$ sodium hypochlorite $(\mathrm{NaOCl})$ solution for $5 \mathrm{~min}$ and subsequently rinsed five times with sterilized water. Seeds were placed on double-layered Whatman $\mathrm{N}^{\circ} 10$ filter paper moistened with $10 \mathrm{~mL}$ of distilled water in sterilized $15 \mathrm{~cm}$ diameter Petri dishes. All the dishes were sealed with a strip of parafilm to reduce water loss and placed at $30 / 18{ }^{\circ} \mathrm{C}$ in a germinator.

Each experiment had a randomized complete block design with four replicates and with 25 seeds per Petri dish. Germination counts were made every day for 3 wk. A seed was considered germinated when the tip of the radicle $(2 \mathrm{~mm})$ had grown free of the seed. Each experiment was carried out twice and statistical analysis was performed on the mean of the two replicates. The germination index (GI) was calculated as described by the Association of Official Seed Analysts (1990) by the following formula:

\begin{tabular}{|c|c|}
\hline $\begin{array}{l}\mathrm{N}^{\circ} \text { of germinated } \\
\text { seeds }\end{array}$ & 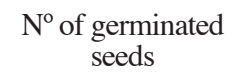 \\
\hline
\end{tabular}


Time needed for $50 \%$ germination of seedlings $\left(\mathrm{T}_{50}\right)$ was calculated according to the following formulae from Coolbear et al. (1984):

$$
\begin{aligned}
& \left(N / 2-n_{i}\right)\left(t_{j}-t_{i}\right) \\
& T_{50}=t i+---------------- \\
& n_{j}-n_{i}
\end{aligned}
$$

where $N$ is the final number of germinated seeds, $n_{i}$ and $n_{j}$ are the cumulative number of seeds germinated by adjacent counts at times $t_{i}$ and $t_{j}$, respectively, when $n_{i}<$ $\mathrm{N} / 2<n_{j}$.

Mean germination time (MGT) was calculated according to the Ellis and Roberts (1981) equation:

$$
\mathrm{MGT}=\sum\left(\mathrm{D}_{\mathrm{n}}\right) / \sum \mathrm{n}
$$

where $n$ is the number of germinated seeds or emerged seedlings on day $\mathrm{D}$ and $\mathrm{D}$ is the total number of days counted from the beginning of germination.

Data were recorded for up to $14 \mathrm{~d}$ and then analyzed statistically by Fisher's ANOVA function of the MSTAT statistical computer package, and LSD at $5 \%$ probability was used to compare the treatment means (Steel et al., 1997).

\section{RESULTS AND DISCUSSION}

\section{Seed treatment with thiourea and $\mathrm{KNO}_{3}$}

Seeds of $R$. capitata showed no response to various concentrations of thiourea and $\mathrm{KNO}_{3}$ since thiourea and $\mathrm{KNO}_{3}$ failed to crack the seed coat and its imbibition. Seeds after the prescribed soaking treatments were still hard and viable, and they successfully germinated when scarified with sandpaper.

Since seeds did not germinate at various treatments with thiourea and $\mathrm{KNO}_{3}$, data regarding these treatments were not included in the calculations.

\section{Scarification with $\mathbf{H C l}$ and sandpaper}

Treatment with sandpaper was very effective in breaking seed dormancy (Table 1). Results indicated that the germination of seeds that were mechanically scratched with sandpaper significantly increased to $100 \%$ as compared to $\mathrm{HCl}$ treatments. In addition, seeds mechanically scarified with sandpaper had the minimum response time $(0.66 \mathrm{~d})$ and mean germination time $(2.16$ d) when compared to all other treatments. When seeds were scarified with $\mathrm{HCl}(36 \%)$ for $3,6,9,12,15$, and $18 \mathrm{~h}$, seed germination significantly $(\mathrm{p}<0.05)$ increased over the control (Table 1). Seeds treated with $\mathrm{HCl}$ for 12,15 , and $18 \mathrm{~h}$ had the minimum response time with $50 \%$ of the seeds germinating in all the replicates within $1.75,1.13$, and $1.20 \mathrm{~d}$, respectively. Minimum MGT (2.94 and $2.95 \mathrm{~d}$ ) was detected in seeds treated with $\mathrm{HCl}$ for 18 and $15 \mathrm{~h}$, respectively. Both were statistically similar. Seeds treated with $\mathrm{HCl}$ for 3,6 , and $9 \mathrm{~h}$ had a significantly higher mean germination time than other treatments, but remained equal to each another. Maximum GI (7.75) was

\begin{tabular}{|c|c|c|c|c|}
\hline Treatments & Germination & $\mathrm{T}_{50}$ & MGT & GI \\
\hline & $\%$ & & & \\
\hline Control & $0.00 \mathrm{f}$ & $0.00 \mathrm{~g}$ & $0.00 \mathrm{e}$ & $0.00 \mathrm{~g}$ \\
\hline $\mathrm{HCl}(3 \mathrm{~h})$ & $17.50 \mathrm{e}$ & $3.62 \mathrm{a}$ & $4.08 \mathrm{ab}$ & $0.47 \mathrm{f}$ \\
\hline $\mathrm{HCl}(6 \mathrm{~h})$ & $25.00 \mathrm{e}$ & $3.25 b$ & $4.37 \mathrm{a}$ & $0.69 \mathrm{f}$ \\
\hline $\mathrm{HCl}(9 \mathrm{~h})$ & $35.00 \mathrm{~d}$ & $2.25 \mathrm{c}$ & $4.15 \mathrm{ab}$ & $1.35 \mathrm{e}$ \\
\hline $\mathrm{HCl}(12 \mathrm{~h})$ & $65.00 \mathrm{c}$ & $1.75 \mathrm{~d}$ & $3.88 \mathrm{~b}$ & $3.11 \mathrm{c}$ \\
\hline $\mathrm{HCl}(15 \mathrm{~h})$ & $90.00 \mathrm{~b}$ & $1.13 \mathrm{e}$ & $2.95 \mathrm{c}$ & $6.00 \mathrm{~b}$ \\
\hline $\mathrm{HCl}(18 \mathrm{~h})$ & $35.00 \mathrm{~d}$ & $1.20 \mathrm{e}$ & $2.94 \mathrm{c}$ & $2.19 \mathrm{~d}$ \\
\hline Sand paper & $100.0 \mathrm{a}$ & $0.66 \mathrm{f}$ & $2.16 \mathrm{~d}$ & $7.75 \mathrm{a}$ \\
\hline $\operatorname{LSD}(\mathrm{P}<0.05)$ & 8.8119 & 0.3669 & 0.4497 & 0.4668 \\
\hline
\end{tabular}
observed in sandpaper scarification and after $6 \mathrm{~d}$ when
Table 1. Effect of seed scarification with $\mathrm{HCl}$ on breaking dormancy and germination of Rhynchosia capitata.

Means followed by the same letter in a column did not differ significantly according to LSD test $(\mathrm{P}<0.05)$.

T50: Time needed for $50 \%$ germination; MGT: Mean germination time; GI: Germination index; LSD: Least significance difference.

seeds were treated with $\mathrm{HCl}$ for $15 \mathrm{~h}$. However, there was no germination in the control treatment.

\section{Scarification with $\mathrm{HNO}_{3}$}

Soaking $R$. capitata seeds in $\mathrm{HNO}_{3}$ for 1 to $5 \mathrm{~d}$ had little effect on seed germination as compared to other treatments (Table 2). Total germination was not more than $18 \%$, slow, and irregular. Percentages of seed germination in all $\mathrm{HNO}_{3}$ treatments were statistically equal to each other. Minimum $\left(\mathrm{T}_{50}\right)$ germination and MGT were recorded in seeds treated with $\mathrm{HNO}_{3}$ for 3, 4, and $5 \mathrm{~d}$, respectively. The control treatment (untreated) had no effect on germination. The remaining seeds were still hard and viable, but successfully germinated when scarified

\begin{tabular}{|c|c|c|c|c|}
\hline Treatments & Germination & $\mathrm{T}_{50}$ & MGT & GI \\
\hline & $\%$ & 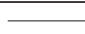 & 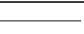 & \\
\hline Control & $0.00 \mathrm{~b}$ & $0.00 \mathrm{~d}$ & $4.41 \mathrm{a}$ & $0.28 \mathrm{~b}$ \\
\hline $\mathrm{HNO}_{3}(1 \mathrm{~d})$ & $12.50 \mathrm{a}$ & $4.31 \mathrm{a}$ & $3.91 \mathrm{ab}$ & $0.47 \mathrm{a}$ \\
\hline $\mathrm{HNO}_{3}(2 \mathrm{~d})$ & $17.50 \mathrm{a}$ & $3.25 \mathrm{~b}$ & $3.58 \mathrm{ab}$ & $0.59 \mathrm{a}$ \\
\hline $\mathrm{HNO}_{3}(3 \mathrm{~d})$ & $17.50 \mathrm{a}$ & $2.50 \mathrm{c}$ & $3.33 b$ & $0.43 \mathrm{ab}$ \\
\hline $\mathrm{HNO}_{3}(4 \mathrm{~d})$ & $15.00 \mathrm{a}$ & $2.50 \mathrm{c}$ & $3.33 b$ & $0.59 \mathrm{a}$ \\
\hline $\mathrm{HNO}_{3}(5 \mathrm{~d})$ & $17.50 \mathrm{a}$ & $2.50 \mathrm{c}$ & $3.33 b$ & $0.59 \mathrm{a}$ \\
\hline $\operatorname{LSD}(\mathrm{P}<0.05)$ & 7.0031 & 0.7363 & 1.0325 & 0.1698 \\
\hline
\end{tabular}
with sandpaper.

Table 2. Effect of seed scarification with $\mathrm{HNO}_{3}$ on breaking dormancy and germination of Rhynchosia capitata.

Means followed by the same letter in a column did not differ significantly according to LSD test $(\mathrm{P}<0.05)$.

T50: Time needed for 50\% germination; MGT: Mean germination time; GI: Germination index; LSD: Least significance difference.

\section{Scarification with $\mathrm{H}_{2} \mathrm{SO}_{4}$}

Scarification of $R$. capitata seed with $\mathrm{H}_{2} \mathrm{SO}_{4}$ induced seed germination in all treatments (Figure 1). The seed germination percentage increased with increasing soaking time (up to $80 \mathrm{~min}$ ) and began to decrease with the further increase in soaking time. Seeds soaked in $\mathrm{H}_{2} \mathrm{SO}_{4}$ for 60 and $80 \mathrm{~min}$ had the most rapid response time with $50 \%$ of the seeds germinating in all replicates within 0.66 and 0.80 d, respectively (Figure 2). Minimum MGT (2.09 and $2.15 \mathrm{~d}$ ) was detected with 60 and $80 \mathrm{~min}$ of soaking in $\mathrm{H}_{2} \mathrm{SO}_{4}$. Maximum GI was recorded when seeds were soaked in $\mathrm{H}_{2} \mathrm{SO}_{4}$ for $60 \mathrm{~min}$. There was no germination in the control treatment. 


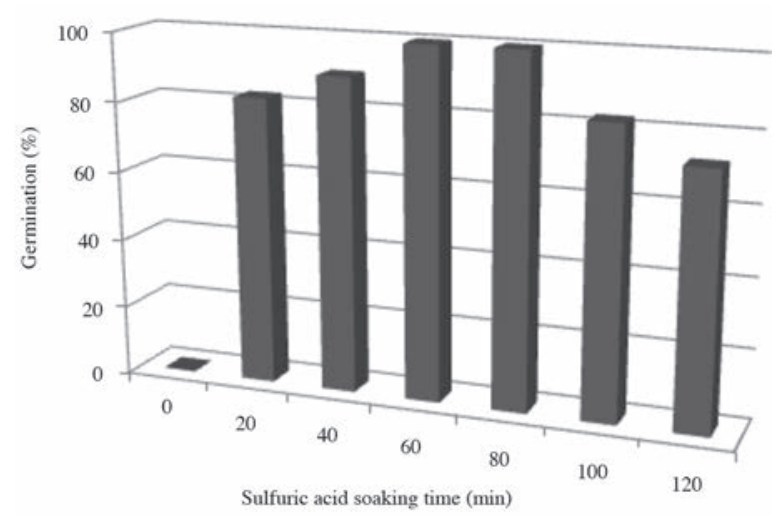

Figure 1. Effect of seed scarification with $\mathrm{H}_{2} \mathrm{SO}_{4}$ on Rhynchosia capitata germination $(\mathrm{LSD}(\mathrm{P}<0.05)=\mathbf{4 . 8 1 3 4})$.

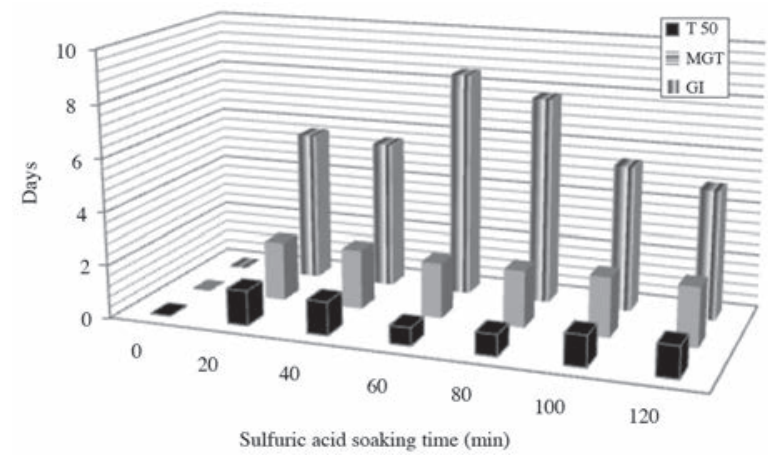

T50: Time needed for 50\% germination; MGT: Mean germination time; GI: Germination index; LSD: Least significance difference.

Figure 2. Effect of seed scarification with $\mathrm{H}_{2} \mathrm{SO}_{4}$ on $\mathrm{T}_{50}$, MGT, and GI of Rhynchosia capitata (LSD $\mathrm{P}<0.05$ for $\mathrm{T}_{50}=0.4397$, MGT $=0.0576$, and $\mathbf{G I}=\mathbf{0 . 4 3 8 6}$ ).

Mechanical constraint, including prevention of water and oxygen uptake, and retention or production of chemical inhibitors are some of the possible mechanisms that cause the strong inhibitory effect of the seed coat on seed germination (Taiz and Zeiger, 2002). The results of various treatments in our study confirm that $R$. capitata seeds exhibit dormancy due to their hard seed coat. Breaking down impermeability of the seed coat by scarification methods resulted in a considerable increase in the germination percentage (12 to $100 \%$ ). The different chemicals (thiourea and $\left.\mathrm{KNO}_{3}\right)$ and acids $\left(\mathrm{HCl}, \mathrm{HNO}_{3}\right.$, and $\left.\mathrm{H}_{2} \mathrm{SO}_{4}\right)$ have been widely used for breaking dormancy of many hard seed coat species, such as European milkvetch (Astragalus hamosus L.), blackdisk medick (Medicago orbicularis [L.] Bartal). (Patane and Gresta, 2006), and Albizia spp. (Tigabu and Oden, 2001). In the present study, the best treatment to remove hard seed dormancy causing the highest germination percentage was seed scarification with $\mathrm{H}_{2} \mathrm{SO}_{4}$ and sandpaper. Similar results were obtained in experiments with African locust bean (Parkia biglobosa) seeds (Aliero, 2004), European milkvetch and blackdisk medick seeds, (Patane and Gresta, 2006), and Enterolobium contortisiliquum (Vell.) Morong seed (Malavasi and Malavasi, 2004) in which seed dormancy was broken by soaking seeds in $\mathrm{H}_{2} \mathrm{SO}_{4}$ and sandpaper scarification. Mechanical scarification provided rapid as well as the highest imbibitions and the germination percentage in the study as compared with untreated (control) seeds and completely overcame seed coat impermeability.

Hydrochloric acid was used to most closely imitate the stomach environment of animals. Total germination of the HCl-treated seeds increased when compared to the control over an extended period (up to $18 \mathrm{~h}$ ) indicating a slow release from seed dormancy. These results are in line with Goddard et al. (2009) who found that Benghal dayflower seeds exposed to $\mathrm{HCl}$ soaking treatments successfully germinated with little loss of viability after each treatment. Seeds from the 18-h treatment were extremely soft and moldy at the end of the germination test, so lower germination was recorded in this treatment. The mechanism of possible seed germination influenced by $\mathrm{H}_{2} \mathrm{SO}_{4}$ is due to its capability to break the seed coat that leads to water absorption and seed imbibition. A gradual increase in the germination percentage and GI and decrease in MGT and $\mathrm{T}_{50}$ with an increase in the soaking time of seeds in $\mathrm{HCl}$ from 3 to $15 \mathrm{~h}$ and treatment with $\mathrm{H}_{2} \mathrm{SO}_{4}$ for $20,40,60$, and 80 min revealed that $\mathrm{HCl}$ and $\mathrm{H}_{2} \mathrm{SO}_{4}$ were adequate to break the hard seed coat of $R$. capitata seeds in order to induce germination.

The decline in the germination rate at 100 and 120 min soaking in $\mathrm{H}_{2} \mathrm{SO}_{4}$ and $18 \mathrm{~h}$ soaking in $\mathrm{HCl}$ was the result of the damaging effect to the seed embryo due to prolonged soaking time. A similar response was observed by Sadeghi et al. (2009) who found that the complete removal of the seed coat caused rapid imbibitions, which caused fracture and bursting of the endosperm. Similarly, Aliero (2004) reported that prolonged emersion of seeds in $\mathrm{H}_{2} \mathrm{SO}_{4}$ injures the seeds since the acid can break vital parts of the embryo.

Thiourea has been known to stimulate germination by reducing the preventive effect of the seed coat in sweet cherry (Prunus avium L.) seeds (Çetinbaş and Koyuncu, 2006). Similarly, $\mathrm{KNO}_{3}$ was very effective in breaking dormancy of many species (Previero et al., 1996), and it has been stated as being a growth-regulating substance in Salvia species (Yücel, 2000). Both these chemicals were unable to break dormancy in $R$. capitata seeds in the present study. This could be due to its excessively hard seed coat. These studies indicated that the success of this species is largely attributed to the occurrence of seed dormancy, which allows the seed to persist for long periods in the soil and thus escape the effects of postgermination weed control measures. 


\section{CONCLUSIONS}

The results of these experiments showed that $R$. capitata seeds were in a dormant state and softening the seed coat by soaking concentrated $\mathrm{H}_{2} \mathrm{SO}_{4}, \mathrm{HCl}$, and $\mathrm{HNO}_{3}$ significantly increased seed germination. Mechanical scarification has also been shown as the best method to overcome this coat-imposed dormancy. Seed coat was the major barrier to Rhynchosia capitata seed germination since the treatments that induce germination were those that can break the seed coat.

\section{Métodos para romper la dormancia de Rhynchosia capitata, una maleza anual de verano. La dormancia seminal de las malezas es un rasgo significativo contribuyente a su tasa de supervivencia, puesto que ayuda a las malezas a evitar herbicidas y otras prácticas de desmalezado junto con condiciones ambientales desfavorables. Investigamos los efectos de diferentes tratamientos para romper dormancia sobre la germinación de Rhynchosia capitata, una maleza anual estival común en Paquistán. Las semillas se sumergieron en tiourea, $\mathrm{KNO}_{3}, \mathrm{HCl}, \mathrm{HNO}_{3}$ y $\mathrm{H}_{2} \mathrm{SO}_{4}$ y además fueron escarificadas mecánicamente (papel lija). Los resultados indicaron que las semillas de $R$. capitata muestran signos de dormancia física principalmente debido a impermeabilidad de su cubierta. Escarificación mecánica y ácida (inmersión de semillas en $\mathrm{H}_{2} \mathrm{SO}_{4}$ por 60 y 80 min y en $\mathrm{HCl}$ por 12 y $15 \mathrm{~h})$ fueron muy eficientes para romper dormancia y promover germinación. Las semillas sumergidas en $\mathrm{HNO}_{3}$ por 1 a 5 días mostraron poco efecto, mientras diversas concentraciones de tiourea y $\mathrm{KNO}_{3}$ fueron inefectivas para romper dormancia seminal en $R$. capitata.}

Palabras clave: $\mathrm{HCl}, \mathrm{HNO}_{3}, \mathrm{H}_{2} \mathrm{SO}_{4}$, dormancia, germinación.

\section{LITERATURE CITED}

Adinarayana, D., P. Ramachandraiah, and K.N. Rao. 1985. Flavonoid profiles of certain species of Rhynchosia of the family Leguminosae (Fabaceae). Experientia 41:251-252.

Aliero, B.L. 2004. Effects of sulphuric acid, mechanical scarification and wet heat treatments on germination of seeds of African locust bean tree, Parkia biglobosa. African Journal of Biotechnology 3:179-181.

Association of Official Seed Analysts. 1990. Rules for testing seeds. Journal of Seed Science and Technology 12:1-112.

Baskin, C.C., and J.M. Baskin. 1998. SEEDS - Ecology, biogeography, and evolution of dormancy and germination. p. 5-26. Academic Press, New York, USA.

Brasil. 2009. Regras para análise de sementes. p. 365. Ministério da Agricultura, Pecuária e Abastecimento, Secretaria de Defesa Agropecuária, Brasília, Brasil.

Cavalheiro, A.L., J.A. Pimenta, and J.M.D. Torezan. 2007. Effect of some physical and chemical treatments on germination of Colubrina glandulosa seeds. Seed Science and Technology 35:744-748.

Çetinbaş, M., and F. Koyuncu. 2006. Improving germination of Prunus avium L. Seeds by gibberellic acid, potassium nitrate and thiourea. Horticultural Science 33:119-123.
Coolbear, P., A. Francis, and D. Grierson. 1984. The effect of low temperature pre-sowing treatment on the germination performance and membrane integrity of artificially aged tomato seeds. Journal of Experimental Botany 35:1609-1617.

Davis, T.D., S.W. George, A. Upadhaya, and J.M. Parsons. 1991. Improvement of seedling emergence of Lupinus texensis following seed scarification treatments. Journal of Environmental Horticulture 9:17-21.

Dogra, K.S., S.K. Sood, P.K. Dobhal, and S. Kumar. 2009. Comparison of understorey vegetation in exotic and indigenous tree plantations in Shivalik Hills of N.W. Indian Himalayas (Himachal Pradesh). Journal of Ecology and the Natural Environment 1(5):130-136.

Ellis, R.A., and E.H. Roberts. 1981. The quantification of aging and survival in orthodox seeds. Seed Science and Technology 9:373409.

Finch-Savage, W.E., and G. Leubner-Metzger. 2006. Seed dormancy and the control of germination. New Phytologist 171:501-523.

Goddard, R.H., T.M. Webster, R. Carter, and T.L. Grey. 2009. Resistance of Benghal dayflower (Commelina benghalensis) seeds to harsh environments and the implications for dispersal by mourning doves (Zenaida macroura) in Georgia, USA. Weed Science 57:603-612.

Gu, X-Y., F. Kianian, and M.E. Foley. 2004. Multiple loci and epistases control genetic variation for seed dormancy in weedy rice (Oryza sativa). Genetics 166:1503-1516.

ILDIS. 2010. International Legume Database and Information Service. Available at http://www.ildis.org/LegumeWeb (accessed 11 January 2010).

Jahan, B., A.A. Vahidy, and S.I. Ali. 1994. Chromosome numbers in some taxa of Fabaceae mostly native to Pakistan. Annals of the Missouri Botanical Garden 81:792-799.

Mackay, W.A., T.D. Davis, D. Sankhla, and D.E. Riemenschneider. 1996. Factors influencing seed germination of Lupinus perennis. Journal of Environmental Horticulture 14:167-169.

Malavasi, U.C., and M. Malavasi. 2004. Dormancy breaking and germination of Enterolobium contortisiliquum (Vell.) Morong seed. Brazilian Archives of Biology and Technology 47:851-854.

Patane, C., and F. Gresta. 2006. Germination of Astragalus hamosus and Medicago orbicularis as affected by seed coat dormancy breaking techniques. Journal of Arid Environment 67:165-173.

Previero, C.A., L. Martins, R.H.A. Fonseca, and D. Groth. 1996. Effect of storage of guinea grass (Panicum maximum Jacq.) on treatment to break dormancy. Revista Brasileira de Sementes 18:143-148.

Radosevich, S.R., J.S. Holt, and C.M. Ghersa. 1996. Weed ecology implications for management. $2^{\text {nd }} e d$. John Wiley, New York, USA.

Roberto, L.B., A.S. Rodolfo, F. Forcella, B.C. Kruk, and C.M. Ghersa. 2000. Environmental control of dormancy in weed seed banks in soil. Field Crops Research 67:105-122.

Sadeghi, S., Z.Y. Ashrafi, F. Tabatabai, and H.M. Alizade. 2009. Study methods of dormancy breaking and germination of common madder (Rubia tinctorum L.) seed in laboratory conditions. Botany Research International 2:7-10.

Sharma, N.K., M.M. Sharma, and D.N. Sen. 1978. Seed perpetuation in Rhynchosiacapitata DC. Biologia Plantarum 20:225-228.

Steel, R.G.D., J.H. Torrie, and D.A. Dickey. 1997. Principles and procedures of statistics. A biometrical approach. p. 172-177. $3^{\text {rd }}$ ed. McGraw Hill Book, Tuas Basin Link, Singapore.

Taiz, L., and E. Zeiger. 2002. Plant physiology. Chapter 23. Abscisic acid: A seed maturation and antistress signal. $3^{\text {rd }}$ ed. p. 538-558. Sinauer Associates, Sunderland, Massachusetts, USA.

Tigabu, M., and P.C. Oden. 2001. Effect of seed scarification, gibberellic acid and temperature on seed germination of two multipurpose Albizia species from Ethiopia. Seed Science and Technology 29:11-20.

Yücel, E. 2000. Effects of different salt $(\mathrm{NaCl})$, nitrate $\left(\mathrm{KNO}_{3}\right)$ and sulphuric acid $\left(\mathrm{H}_{2} \mathrm{SO}_{4}\right)$ concentrations on the germination of some salvia species seeds. Seed Science and Technology 28:853-860. 